\title{
The Impact of Gasoline Subsidy Removal on the Transportation Sector in Nigeria
}

\author{
Ismail O. Soile*, Hezekiah Tsaku, Bilikisu Musa Yar'Adua \\ CEPMLP, University of Dundee, United Kingdom \\ *Corresponding author: iosoile@yahoo.com
}

Received May 27, 2014; Revised June 08, 2014; Accepted June 10, 2014

\begin{abstract}
Nigeria, like other oil exporting countries in the world has embarked on the policy of gradual removal of fuel subsidies since 1970s. However, this issue has become highly contentious in recent time due to the incessant nature and the effects on the economy. To this end the paper examine the impact of subsidy removal on transport sector development in Nigeria using the co-integration and error-correction models. The result showed that subsidy had a positive and significant relationship with transport sector which implies that removing gasoline subsidies can increase the operational cost of transportation sector and reduce the gross domestic product (GDP) of the country.
\end{abstract}

Keywords: gasoline, subsidy, transportation sector, Nigeria

Cite This Article: Ismail O. Soile, Hezekiah Tsaku, and Bilikisu Musa Yar'Adua, "The Impact of Gasoline Subsidy Removal on the Transportation Sector in Nigeria.” American Journal of Energy Research, vol. 2, no. 3 (2014): 60-66. doi: 10.12691/ajer-2-3-3.

\section{Introduction}

Nigeria is a country endowed with vast mineral resources prominent among which are the oil and gas reserves. The country possesses $28 \%$ of Africa's proven oil reserves, second only to Libya; and is the largest producer of crude oil in the region, producing 2.4 million barrels per day in 2010 which is about 24\% of the continent's petroleum (Siddig, et al, 2013). The country has four refineries with an installed production capacity of 445,000 barrels of fuel per day, adequate to meet its domestic needs with a surplus for export. However, Nigeria is a large net importer of gasoline and other petroleum products. In spite of efforts to revamp her economy via various reforms, which includes comprehensive non-oil export diversification initiatives, petroleum still contributes an average of 95\% of the nation's external earnings (Majekodunmi, 2013). The country increasingly relies on imported petroleum products because the existing refineries are producing below $20 \%$ of their installed capacity. In fact, the cost of importing petroleum products has risen so rapidly in recent years that the country's capital expenditures and balance of payment are under threat (Adelabu, 2012).

An interesting matter from the economy is the issue of fuel subsidy removal, which has been of a great controversy for Nigerians. They are disappointed that despite their disapproval of the plan, government has remained adamant. The issue of fuel subsidy removal has been on in Nigeria for some decades of which different governments have tried the reform but were unsuccessful due to fierce public demonstration of its disapproval.

Subsidy, in economic sense, exists when consumers of a given commodity are assisted by the government to pay less than the prevailing market price of it. In respect of fuel subsidy, it means that consumers would pay less than the pump price per litre of gasoline. Also, fuel subsidy could be described as the difference between the actual market price of petroleum products per litre and what the final consumers pay for those same products. Developing countries have used fossil fuel subsidies for consumers primarily as a means of achieving certain social, economic, and environmental objectives, as identified by Bazilian and Onyeji, (2012). These include alleviating energy poverty and improving equity, increasing domestic supply, national resource wealth redistribution, correction of externalities and controlling inflation.

The transportation sector, being the commercial hub of Nigeria, has been more affected by the fuel subsidy removal reform. Modern businesses, industries, trades and general activities depend on the sector, with movement of goods and services from place to place becoming vital and inseparable aspects of global and urban economic survival. Developments of different transportation modes have become necessary to physical and economic developments in Nigeria. The research therefore seeks to examine the impact of subsidy removal on urban road transport in Nigeria.

The research utilizes the Co-integration and ErrorCorrection Model (ECM) in order to examine the relationship between subsidized gasoline prices and transport sector from 1995-2013 by adopting the multifactor neoclassical production function framework. It employs basically the use of secondary data in sourcing information. The research is structured as follows: Section one is the introduction, section two covers the literature review, section three is the methodology, empirical results and analysis are in section four while the final section covers the conclusion and recommendations. 


\section{Literature Review}

\subsection{The Concept of Subsidy}

Consumption subsidy is a pricing design that keeps the price consumers pay for products below market levels to specifically make targeted goods and services affordable to consumers who ordinarily may not be able to afford them. Subsidies could benefit people and businesses in the form of tax deductions, grants, exemptions or price control. In Nigeria, fuel subsidy as designed in the Petroleum Product Pricing Regulatory Agency (PPPRA, 2013) template is the compensation due to importers of petroleum products based on the difference between landing cost less ex-depot price of fuel. This is to ensure that consumers pay a regulated amount of gasoline at the same time, ensuring that producers get their real costs remunerated. It is a scheme meant to alleviate poverty by providing energy security for the country. Subsidies affect prices or costs indirectly, such as regulations that tilt the market in favour of a specific fuel, government funded technology or research and development (Adebiyi, 2011).

Successful Nigerian governments have continually removed part of this subsidy claiming that prices paid by Nigerians to use petroleum products are less than what they should pay particularly when benchmarked against the prices in the international market and will provide necessary impetus for the Nigerian economy to find its rhythm (Onyeizugbe and Onwuka, 2012). This was further reiterated by Plante, (2013), noting that subsidies especially on petroleum products are an important policy issue for many developing and emerging market economies because of the steep costs they impose on the governments that provide them.

Fuel subsidy is particularly popular in oil producing countries like Iran, Venezuela, China, Saudi Arabia, India, Indonesia, Egypt and Ukraine, (Nwachukwu and Chike, 2011). Fuel subsidy removal programs are sensitive to economic structure, level of development of the country, political systems and the state of the economy. There is evidence that the more successful countries have taken a phased or gradual approach, have engaged in conscientious research prior to implementation and followed by a rigorous approach to policy making (Majekodunmi, 2013). That effective communications and a fair level of trust between citizens and governments may be the other critical success factors in such an exercise.

\subsection{Deregulation of the Petroleum Sector}

Deregulation in economics means the reduction or removal of government control in a particular sector or industry so as to create more and better competition within that industry. It is the elimination of government interference in the running of a system (Akinwumi, et al, 2005). This means that the market forces are allowed to determine the swings of operations rather than the state. Deregulation does not allow for restrictions in enterprises and services. One highly conflicting issue in Nigeria is perhaps the question of petroleum industry deregulation, which has been generating debates from its protagonists and antagonists.

The protagonists postulate that the liberalization of the petroleum downstream sector would finally actualize the objective of ending persistent fuel scarcity and maintaining sustainable fuel supply across the society. Also, liberalization and deregulation of the sector would open it up for foreign investments, and, the cases of petroleum products smuggling and inefficiencies in the sector will be greatly mitigated. By the deregulation of the sector, the government would be able to channel funds to other sectors of the economy. The antagonists oppose the total deregulation and liberalization of the petroleum sector for whatever reason but can only be partially reformed for efficiency purposes. As such, the overall national interest will be achieved, (Obayi, et al, 2012).

\subsection{Reforming Fuel Subsidy}

Fuel subsidies are visibly undesirable for a number of reasons (Granado et al, 2012). Subsidies displace higher priority public expenditure, dilute motivations for increasing energy efficiency, encourage domestic shortages due to cross-border smuggling, are economically expensive, and more beneficial to higher income individuals. However, any attempt to reduce subsidies is of serious political contentions. The Federal Government experienced this in Nigeria in 2012 when the general public protested against the purported removal of fuel subsidies. This is because the public does not have trust in government's use of budget savings to the benefit of the masses. Also, there could be a resultant increase in poverty as a result of the subsidy reform, which leads to sizeable reduction in the real incomes of low-income households. Therefore, only reform strategies that seek to address the above constrictions are more likely to succeed.

\subsection{Historical Synopsis of Fuel Subsidy Removal in Nigeria}

Nigeria is a country endowed with ample human and natural resources. In the early 1950s and 1960s, agriculture was the main foreign exchange earner of the country. Other mineral and agricultural resources like coal, tin, rubber, cotton, groundnuts, etc. were explored, and government's expenditures were financed from their proceeds. The discovery of crude oil in commercial quantity at Olobiri in Delta state (in 1956) diverted the country's attention to oil production and exportation. This led to huge foreign exchange earnings and reserves rising to an unprecedented buoyant level and thus, led to the abandonment of other vital sectors like agriculture. To this day, the Nigerian economy has become dependent on oil for most of her economic transactions with rest of the world.

According to Obasi (2003), 95\% of Nigeria’s foreign exchange earnings are accounted by petroleum products. To bolster the effect of underdevelopment and poverty, the government has long been subsidizing the pump prices of petroleum products, such as petrol, kerosene, and diesel. However, following the global economic slump in most countries, the amount paid by the government to subsidize goods and services were gradually reduced to prevent more severe situations. In order to prevent the total failure of the economy, the Federal Government decided to subsidize fuel. Figure 1 and Figure 2 below show the history of fuel subsidy removal in Nigeria from 1966 till date. As can be observed from the two figures, the petroleum subsidy changes have been on increase, 
especially from 1993 and these provide useful experience and lessons that have relevancy to the current policy discourse.

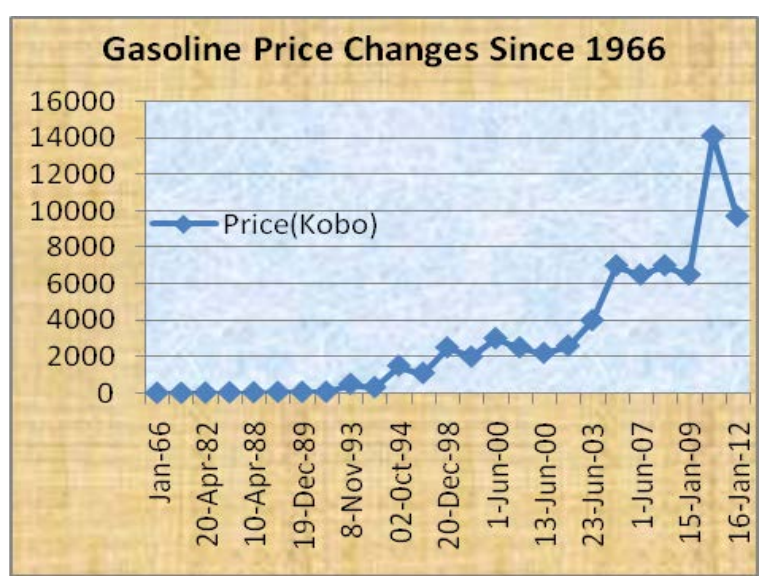

Figure 1. Gasoline Price Changes Since 1966 (Source: Authors Compilation)

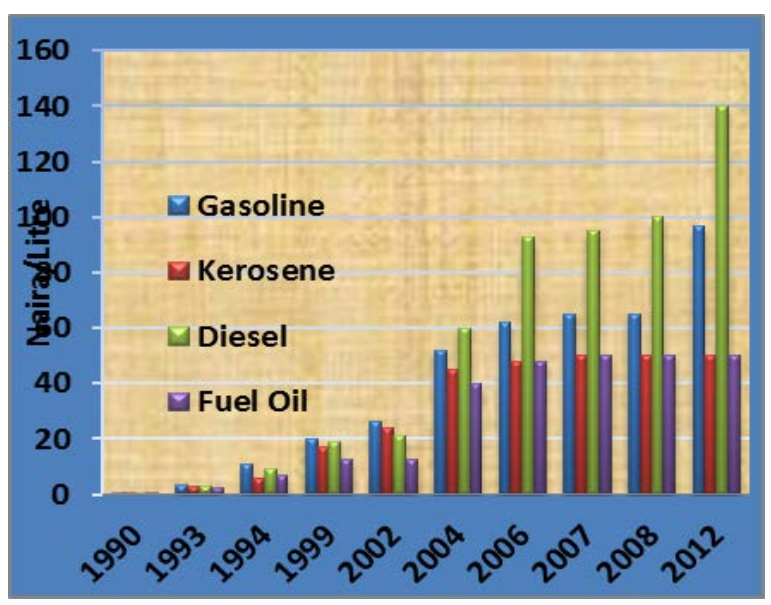

Figure 2. Petroleum Products Nominal Price Increase in Nigeria* Source: Barde (2014)

*Note: Diesel Price was fully deregulated since 2004.

Growth in aggregate petroleum product consumption is driven generally by gasoline, which is the principal fuel in the petroleum product mix despite these variations. In 1978, gasoline share of aggregate consumption rose from $40 \%$ to $64 \%$ in 2010 while for the period 1999-2003 average annual growth was $20.4 \%$ as compared to $13.9 \%$ for aggregate products over the same period. Similarly, average gasoline consumption growth for the period
1979-2010 was 5.1\% compared to $3.4 \%$ for the same aggregate. (Barde, 2014).

\subsection{Transportation Sector Overview}

In Nigeria, transportation modes comprise roads, railways, pipelines, ports, inland waterways and aviation respectively, of which road, trailed by air transport constitute the principal ones. Growth in value-added in transport decelerated from $6.83 \%$ in 2009 to $6.72 \%$ in 2010 on account of slower trade related activities and poor condition of roads and the rail system, as well as high level of insecurity in the country. However, growth in rail transport and pipelines rose from 5.75\% in 2009 to 5.81\% in 2010. The improvement was enhanced by the successful rehabilitation of some rail tracks and equipment as well as reduction in pipeline vandalism. Table 1 summarizes activities in the transport sector in 2010 relative to 2009.

A central requirement for increase in investment and sustainable human development is access to petroleum services. Even though economic growth is vital for attracting investment in the petroleum sector, it is not adequate in driving access to sustainable energy. Data for Nigeria's GDP growth rate showed that within the period 2004-2007, Nigeria's GDP averaged 6.01\% and 6.61\% within 2008-2011. The same periods recorded $2.06 \%$ and $2.19 \%$ growth in transport sector energy access. Energy access in transportation in the country lies below $50 \%$ as shown on the figure below despite a rising trend in GDP and overall energy access.

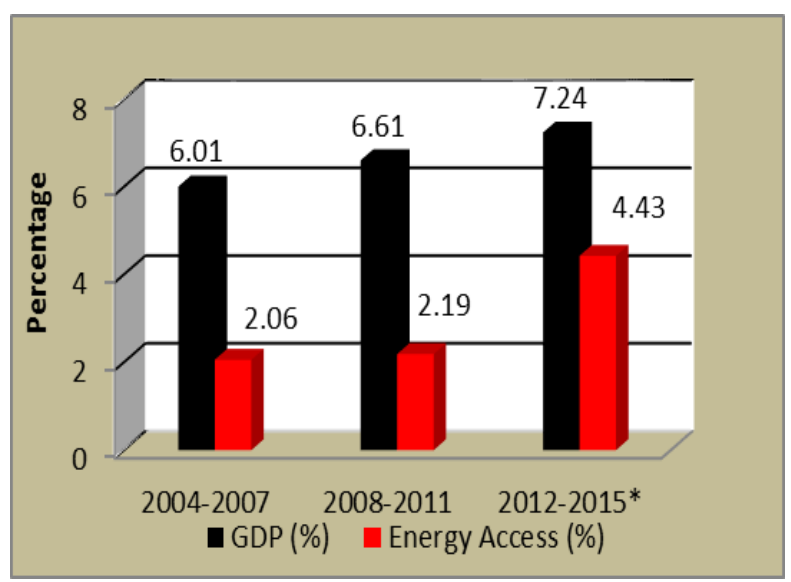

Figure 3. Transport Energy Access and GDP Growth Rate in Nigeria (Source: Authors Compilation using data from Terfa (2014))

Table 1. Value added in the transport sector, 2009-2010

\begin{tabular}{|c|c|c|c|c|c|c|c|c|c|c|}
\hline \multirow{2}{*}{ ACTIVITY SECTOR } & \multicolumn{2}{|c|}{ Real GDP (N'Billions) } & \multicolumn{2}{|c|}{ Nominal GDP } & \multicolumn{2}{|c|}{ \% Annual change } & \multicolumn{2}{|c|}{ \% Distribution } & \multicolumn{2}{|c|}{ Contribution to Growth (\%) } \\
\hline & 2009 & 2010 & 2009 & 2010 & 2009 & 2010 & 2009 & 2010 & 2009 & 2010 \\
\hline Total Transport & 19.5 & 20.8 & 506.7 & 528.3 & 6.8 & 6.7 & 2.7 & 2.7 & 2.7 & 2.3 \\
\hline Road Transport & 17.5 & 18.7 & 475.9 & 495.1 & 6.9 & 6.8 & 2.4 & 2.4 & 2.4 & 2.1 \\
\hline Rail Transport \& Pipelines & 0.0 & 0.0 & 0.0 & 0.0 & 5.8 & 5.8 & 0.0 & 0.0 & 0.0 & 0.0 \\
\hline Water Transport & 0.4 & 0.4 & 1.3 & 1.4 & 5.7 & 5.5 & 0.1 & 0.1 & 0.1 & 0.0 \\
\hline Air Transport & 0.4 & 0.5 & 5.2 & 5.8 & 7.9 & 7.5 & 0.1 & 0.1 & 0.1 & 0.1 \\
\hline Transport Services & 1.1 & 1.1 & 24.3 & 26.0 & 5.5 & 5.5 & 0.2 & 0.2 & 0.1 & 0.1 \\
\hline
\end{tabular}

Source: Derived by NPC from NBS Data on National Accounts (2011)

\subsection{Empirical Literature Review}

Several empirical works have been put forward by researchers in the areas of gasoline price effects on various aspects of the Nigerian economy. Nwosa (2012) examined empirically a one-to-one nexus between domestic fuel price and various macroeconomic variables in Nigeria for the period 1986-2011. The research 
employed a vector auto-regressive (VAR) and a vector error correction (VEC) models for appropriate analysis. The VAR model revealed that a unidirectional causation exist from domestic fuel price to short term interest rate for pairs of variables that are integrated of the same order but not co-integrated while VEC model revealed the existence of causality from domestic fuel price to inflation rate in the long run and in the short run for pair of variables that are integrated of the same order and are cointegrated. Caution should therefore be taken by government on the issue of fuel subsidy removal and the liberalization of the downstream sector of the petroleum industry with respect to increase in gasoline prices (Nwosa\&Ajibola 2013).

Hui-Siang et al., (2011) examined the relationship between domestic petrol price and the 10 principal economic sectors in Malaysia, using quarterly data for the period 1990-2007. The research employed a vector error correction model. Out of the 10 sectors, only the agriculture sector, trade sector and services sectors had a co-movement with fuel prices. Secondly, the significant coefficient for error correction term (ECT) in the sectoral equations showed that beyond the short run, fuel price remained the principal variable for these three economic sectors. Thirdly, unidirectional causality running from mining sector to fuel price was discovered via the standard Granger causality test. Finally, employing the generalized variance decomposition (GVDCs) test, it was established that some of these sectors over a longer period are influenced by the fuel price.

Ehinomen and Adeleke (2012) assessed the distribution of petroleum products in Nigeria, between the periods 1960-2007. To them, the distribution of such products in the country is burdened with complex problems, which sometimes lead to petroleum products outages, hiked prices of products and conflicts on the pump price of products. To them, the downstream activities of the oil industry should be completely deregulated to allow private sector and entrepreneurs' full participation in the distribution of the products so as to drive effectiveness in the sector. As effectiveness is enhanced, operational cost will be cut down with a resultant reduction in the price of petroleum products that will be beneficial to all stakeholders in the industry.

Therefore, as discussed in the introductory section, it is apparent from the above review that there has been neglect among the previous studies on effect of gasoline (that is, petrol) price on transport sector in the Nigerian economy. This study therefore fills this gap in literature by examining the effect of gasoline subsidy removal on transport sector growth in Nigeria.

\section{Methodology}

\subsection{Data and Sources}

This study examines the relationship between gasoline price subsidy and transport sector of the Nigerian economy. Data on gasoline-subsidized price are obtained from the Nigeria National Petroleum Corporation (NNPC) statistical bulletin and from the works of Ekine \& Okidim (2013). Also, data used for transport sector development are obtained from the work of Okezie, et al (2012).

\subsection{Method of Analysis}

To examine the short run and the long run relationship between gasoline subsidized price and transport sector, this research employed the co-integration and ErrorCorrection Methodology (ECM). The Co-integration approach provides information about the long run relationship between the variables while the ErrorCorrection Method (ECM) provides information about the short-run relationship between the variables. The error correction term provides information on the speed of adjustment from the short run disequilibrium to the long run equilibrium in the event of any deviations from the long run equilibrium.

\subsection{Model Specification}

To examine the relationship between subsidized gasoline price and transport sector, this study adopted the multifactor neoclassical production function framework. The model is expressed as:

$$
\operatorname{Tr}=f(S P P, U P P, P Q)
$$

Where $\mathrm{Tr}=$ Transport sector's output

SP-subsidized petroleum price

$\mathrm{UPP}=$ unsubsidized petroleum price

$\mathrm{PQ}=\mathrm{PMS}$ sales per litre.

Specifying equation one in an exponential form, we have;

$$
\operatorname{Tr}=\lambda_{o} S P P^{\beta_{1}} U P P^{\beta_{2}} P Q^{\beta_{3}} e^{\varepsilon_{t}}
$$

Linearizing equation (2), we obtain;

$$
\begin{aligned}
\ln T r= & \ln \lambda_{o}+\beta_{1} \ln S P P+\beta_{2} \ln S P P \\
& +\beta_{2} \ln P Q+e_{t}
\end{aligned}
$$

$\lambda_{0}$, Is intercept, $\beta_{1}$ to $\beta_{3}$ are the slope of the coefficients of the independent variables to be determined where $\varepsilon_{t}$ is the error term at time t. Equation (3) is the long run regression equation to obtain the long run relationship between the variables. In order to estimate the short-run relationship among variables in equation (3), the corresponding error correction equation is estimated as follows:

$$
\begin{aligned}
\Delta \ln T r_{t}= & \lambda_{o}+\sum_{i-1}^{m} \beta_{1} \Delta \ln S P P_{t-i}+\sum_{i-1}^{n} \beta_{2} \Delta \ln U P P_{t-i} \\
& +\sum_{i-1}^{p} \beta_{3} \Delta \ln P Q_{t-i}+\alpha E C M_{t-1}+e_{t}
\end{aligned}
$$

The $E C M_{t-1}$ is the error correction term of the short run equation (equation 3 ).

\section{Results and Analysis of Findings}

\subsection{Unit Root Test}

The research commenced its empirical analysis by testing the properties of the variables using the Augmented Dickey-Fuller (ADF). This is to find out if the relationship between economic variables is spurious or nonsensical. 
Table 2. Summary of Unit Root Test Results

\begin{tabular}{|c|c|c|c|}
\hline Variables & $\begin{array}{c}\text { ADF Test } \\
\text { Statistics }\end{array}$ & $\begin{array}{c}\text { At first } \\
\text { difference }\end{array}$ & $\begin{array}{c}\text { Order of } \\
\text { Integration }\end{array}$ \\
\hline$T R$ & -4.8637 & -4.5326 & $I(1)$ \\
\hline$S P P$ & -5.0454 & -4.5326 & $I(1)$ \\
\hline$U P P$ & -4.6334 & -4.5326 & $I(1)$ \\
\hline$P Q$ & -5.0799 & -4.4983 & $I(0)$ \\
\hline
\end{tabular}

Source: Authors Computation, 2014 (Eview-7 Output)

From the Table 2 above, we found that TR, SPP and UPP were found stationary at first difference and at $1 \%$ level. However, the Petroleum sale (PQ) was stationary at level form and at $1 \%$ level also. These variables (stationary variables) shall be used for further analysis in computing and analysing of our results. The next specification test that shall be computed is the cointegration test of these variables.

\subsection{Co-integration Estimates}

If two or more time series are not stationary, it is important to test whether there is a linear combination of them that is stationary. Economically, variables are co integrated if they have a long term, or equilibrium relationship between them. It is a pre-test to avoid spurious regression situations.

Table 3. Summary of Co-integration Estimates

\begin{tabular}{|c|c|c|c|c|}
\hline \multicolumn{5}{|c|}{ Date: 04/22/14 Time: 11:29 } \\
\hline \multicolumn{5}{|c|}{ Sample (adjusted): 1995-2013 } \\
\hline \multicolumn{5}{|c|}{ Included observations: 19 after adjustments } \\
\hline \multicolumn{5}{|c|}{ Trend assumption: Linear deterministic trend } \\
\hline \multicolumn{5}{|c|}{ Series: TR SPP UPP PQ } \\
\hline \multicolumn{5}{|c|}{ Lags interval (in first differences): 1 to 1} \\
\hline \multicolumn{5}{|c|}{ Unrestricted Cointegration Rank Test (Trace) } \\
\hline Hypothesized & & Trace & 0.05 & \\
\hline No. of CE(s) & Eigenvalue & Statistic & Critical & Prob.** \\
\hline None * & 0.972787 & 135.8951 & 47.85613 & 0.0000 \\
\hline At most $1 *$ & 0.924575 & 67.41769 & 29.79707 & 0.0000 \\
\hline At most $2 *$ & 0.410926 & 18.30996 & 15.49471 & 0.0183 \\
\hline At most $2 *$ & 0.352398 & 8.255106 & 3.841466 & 0.0041 \\
\hline \multicolumn{5}{|c|}{ Trace test indicates 4 cointegrating eqn(s) at the 0.05 level } \\
\hline \multicolumn{5}{|c|}{ * denotes rejection of the hypothesis at the 0.05 level } \\
\hline **MacKinno & $-1 \mathrm{~V}$ & 99) $\mathrm{p}-\mathrm{Va}$ & & \\
\hline
\end{tabular}

\begin{tabular}{|l|l|l|l|l|}
\hline \multicolumn{6}{|l|}{ Unrestricted Cointegration Rank Test (Maximum Eigenvalue) } \\
\hline Hypothesized & & Max-Eigen & 0.05 & \\
\hline No. of CE(s) & Eigenvalue & Statistic & Critical & Prob.** \\
\hline & & & & \\
\hline None * & 0.972787 & 68.47741 & 27.58434 & 0.0000 \\
\hline At most $1 *$ & 0.924575 & 49.10772 & 21.13162 & 0.0000 \\
\hline At most 2 & 0.410926 & 10.05486 & 14.26460 & 0.2083 \\
\hline At most $2 *$ & 0.352398 & 8.255106 & 3.841466 & 0.0041 \\
\hline \multicolumn{5}{|l|}{} \\
\hline Max-eigenvalue test indicates 2 cointegrating eqn(s) at the 0.05 \\
\hline * denotes rejection of the hypothesis at the 0.05 level \\
\hline **MacKinnon-Haug-Michelis (1999) p-values \\
Source: Authors Computation, 2014 (Eview-7) \\
\hline
\end{tabular}

From the Co-integrated result above in Table 3, the trace test indicates four Co-integrating equations at 5\% level. More so, the Max-eigenvalue test indicates two Cointegrating equations at $5 \%$ level. The model thus shows that there exists a long-run equilibrium relationships among the four variables used in the analysis. It shows that the variables move together in the long run.

\subsection{Model Estimation and Analysis}

The ECM result shows how the system adjusts to the long-run equilibrium implied by the co-integrating equation 3. A crucial question concerning the ECM is about the optimal lag for the right-hand-side variables. Hendry's (1987) methodology of "general-to-specific", was employed to eliminate all insignificant lags. Accordingly, this led to an initial estimation of an ECM with three lagged differences of the explanatory variables, a constant term and error correction term lagged one $\left(\mathrm{ECM}_{\mathrm{t}-1}\right)$ The dimensions of the parameter space were then reduced to a parsimonious ECM specification by using omitted and redundant variable test to exclude the statistically insignificant lags. The results of the reduced short-run dynamic transport-petroleum subsidy model are presented in Table 4 below.

Table 4. Parsimonious Error Correction Model Result Dependent Variable: D(TR)

\section{Method: Least Squares}

Date: $04 / 22 / 14$ Time: $12: 14$

Sample (adjusted): 19972013

Included observations: 17 after adjustments

\begin{tabular}{|c|c|c|c|c|}
\hline Variable & Coefficien & Std. Error & t-Statistic & Prob. \\
\hline $\mathrm{C}$ & 378.6277 & 259.3744 & 1.4598 & 0.1946 \\
\hline $\mathrm{D}(\mathrm{TR}(-2))$ & 0.9535 & 0.2275 & 4.1918 & 0.0057 \\
\hline $\mathrm{D}(\mathrm{TR}(-3))$ & 0.6039 & 0.2729 & 2.2130 & 0.0689 \\
\hline $\mathrm{D}(\mathrm{SPP})$ & 122.3601 & 25.8327 & 4.7366 & 0.0032 \\
\hline$\overline{\mathrm{D}(\mathrm{SPP}(-1))}$ & 222.9109 & 67.3602 & 3.3092 & 0.0162 \\
\hline $\mathrm{D}(\mathrm{SPP}(-2))$ & 138.2047 & 44.8623 & 3.0806 & 0.0216 \\
\hline D(UPP(-1)) & -140.1248 & 33.3211 & -4.2053 & 0.0057 \\
\hline D(UPP(-2)) & -246.1224 & 54.2643 & -4.5356 & 0.0040 \\
\hline D(UPP(-3)) & -280.0587 & 55.4438 & -5.0512 & 0.0023 \\
\hline $\mathrm{D}(\mathrm{PQ}(-2))$ & $-9.32 \mathrm{E}-05$ & $3.67 \mathrm{E}-05$ & -2.5416 & 0.0440 \\
\hline ECM(-1) & -0.3472 & 0.1274 & -2.7244 & 0.0344 \\
\hline R-squared & 0.9415 & \multicolumn{2}{|c|}{ Mean dependent var } & 1507.72 \\
\hline Adjusted R- & 0.8440 & \multicolumn{2}{|c|}{ S.D. dependent var } & 1515.55 \\
\hline S.E. of regression & 598.50 & \multicolumn{2}{|c|}{ Akaike info criterion } & 15.8794 \\
\hline Sum squared resid & 2149228 & \multicolumn{2}{|c|}{ Schwarz criterion } & 16.4185 \\
\hline Log likelihood & -123.97 & \multirow{2}{*}{\multicolumn{2}{|c|}{ Hannan-Quinn criter. }} & 15.9330 \\
\hline F-statistic & 9.6595 & \multirow{2}{*}{\multicolumn{2}{|c|}{ Durbin-Watson stat }} & 2.0423 \\
\hline Prob(F-statistic) & 0.0059 & & & \\
\hline
\end{tabular}
Source: Authors Computation, 2014 (Eview-7).

As expected, the error-correction term $\left(\mathrm{ECM}_{\mathrm{t}-1}\right)$ is of the expected negative sign, significant and less than unity in the transportation function. This result substantiates the findings of Co-integration among the variables reported earlier, but more importantly, it suggests that one cannot overlook the Co-integrating relationship among variables in the model; otherwise this could introduce misspecification in the underlying dynamic structure. The absolute value of the coefficient of the error correction term indicates that about $34.7 \%$ of the disequilibrium in the transport-petroleum subsidy model is offset by short run adjustment within a year. In this case, the full adjustment is achieved, and takes twelve months to complete the cycles. Thus, to maintain a long-run equilibrium, it is important to reduce the existing disequilibrium overtime. 
In addition to the disequilibrium effect, the results in Table 4 show that transport sector is influenced by changes in the first and second lags of subsidized petroleum price, first, second and third lags of unsubsidized petroleum price and second lag of petroleum quantity supplied.

More so, the parsimonious model is free of serial correlation going by the value of the Durbin-Watson value of 2.04. The coefficient of determination (R-square) at 0.94 , used to measure the goodness of fit of the estimated model, indicates that the model is reasonably fit in prediction, that is, the model explains about $94 \%$ of the transport sector growth in Nigeria.

The parameter estimates for current, first and second lags of subsidized petroleum price are correctly signed and highly significant at 5\%. This shows that subsidized gasoline price brings about reduced operational cost of transportation sector, and adds to the gross domestic product (GDP) of the country. The evident of these subsidies shows in the reduced transportation fares, and thus helps to ameliorate the transportation suffering of the masses. The multiplier effects of these will manifest in a sporadic increase in investment rates and attraction of foreign direct investment in the economy. The function thus shows that a one percent change in the current, first and second lag of subsidized petroleum price results to $122.36 \%$, 222.91\% and $138.20 \%$ increase in transport sector growth.

The unsubsidized petroleum price was found to be statistically significant, but is inversely related to the transportation sector growth. This is in agreement with Majekodunmi (2013) who argued that removal of subsidies at this point in time could compound the already unbearable economic hardship that Nigerians are currently experiencing. These include hikes in transport fare, prices of food and services, closure of local industries and job losses and unemployment, deepening of the poverty level and poor standard of living of most Nigerians. Thus, for the unsubsidized petroleum price, a $1 \%$ increase in the first, second and third lagged values of unsubsidized gasoline price would bring about a decrease in transport sector growth by about $140 \%, 246 \%$ and $280 \%$ respectively in the short run. With respect to the PMS sales, it is revealed that in the short run only the previous value of gasoline (PMS) sales per litre had significant and negative effect on transport sector growth. Therefore, a $1 \%$ increases in current gasoline sales with an unsubsidized price would result in a decline of transport sector growth by $9.32 \%$.

\section{Conclusion and Recommendations}

A comprehensive, well-planned, well-communicated and transparent reform strategy gives the best chance of success. Develop alternative sources of energy for domestic and vehicular use so as to reduce the local demand and price of gasoline. The main policy action here is to liberalise product importation and unbundle the underutilized PPMC pipelines and storage systems so that all importers (and not just NNPC) can use them to throughput their imports for onward distribution. Competition will be enhanced thereby curtailing the cartel-like profiteering built into the current import licensing regime that guarantees profit margins set by the government. Of course liberalising importation requires strengthened monitoring to ensure the quality of imported products, which may be the only necessary regulatory function henceforth.

More so, government should create an enabling environment to stimulate private investment for the purpose of improving the local refining capacity with a view to meeting the ever increasing local demand of petroleum products as well as for exports. Related to the above is the need to use the oil windfall proceeds and the savings realized by the federal government from the withdrawal of subsidy to be channelled towards rehabilitation of the existing refineries, building additional ones and upgrading and developing of infrastructure within the polity, in areas such as waterways, rail and mass transit system, thus providing cheaper alternative transportation methods.

The Nigerian government should seek to consider as an alternative policy measure, the use of efficiency subsidies, such as fuel efficiency automobiles in order to shift the demand curve of gasoline inwards. This will inevitably reduce the need for future subsidies and its impact on the transportation sector and other sectors at large.

Finally, if gasoline subsidy must be removed, then there is a dare need to emphasize the importance of taking into cognizance the essential features of a developing country like Nigeria. The Nigerian government needs to put in place key palliative measures prior to such a subsidy reform, in order to ensure that increasing access to high quality energy services (e.g. transportation) is not hindered by such a reform.

\section{References}

[1] Adebiyi, O. (2011): Fuel Subsidy: The True Story Desert Herald Newspaper, November 10, 2011.

[2] Afonne, E. (2011): Politics of Oil Subsidy: The Cartel's Fraudulent Acts. Nigerian News World. October 24, 15(34).

[3] Akinwumi, F.S, and Agwaranze, D.G. (2005). University Education Deregulation Pros and Cons in Akpa, G.O., Udoh S.U., and Fagbamiije, E.O. (Eds). Deregulating the Provision and Management of Education in Nigeria. NAEAP Publication. Jos.

[4] Barde, A.A (2014) Modelling Petroleum Product Demand in Nigeria Using Structural Time Series Model (STSM) Approach. Nigeria Energy Conference, Abuja.

[5] Bazilian, M. and Onyeji, I. (2012). Fossil Fuel Subsidy Removal and Inadequate Public Power Supply: Implications for Businesses. Energy Policy Journal. Vol. 45 1-5.

[6] Ehinomen, C., and Adeleke, A. (2012): An Assessment of the Distribution of Petroleum Products in Nigeria. Journal of Business Management and Economics, 3(6), 232-24.

[7] Ekine, D.I and Okidim, I.A (2013): Analysis of the Effect of Fuel Subsidy Removal on Selected Food Prices in Port Harcourt, Rivers State Nigeria. European Journal of Business and Management. 5(4)

[8] Granado, F.J., Coady, D., and Gillingham, R. (2012). The Unequal Benefits of Fuel Subsidies: A Review of Evidence for Developing Countries, World Development Vol. 40, No. 11.

[9] Hui-Siang, J. B., Evan, L., Chin-Hong, P. and Shazali, A.M. (2011) Domestic fuel price and economic sectors in Malaysia. Journal of Economic and Behavioural Studies. \3(1), 2841.

[10] Majekodunmi, A. (2013).The Political Economy of Fuel Subsidy Removal in Nigeria. International Journal of Management and Social Sciences Research (IJMSSR).2(7).

[11] Nwachukwu, M.U., and Chike, H. (2011).Fuel Subsidy in Nigeria: Fact or Fallacy. Energy Journal. Vol. 36.

[12] Nwaoga, K. C. and Casimir, A. (2013): Fuel Subsidy Removal in Nigeria: Socio-Religious and Value Implications Drawn from the 
Theistic Humanism of Professor Dukor. International Journal of Scientific research 3(1A).

[13] Nwosa, P.I. (2012): Domestic fuel price and the Nigerian macro economy. African Journal Economic and Sustainable Development (in press).

[14] Nwosa, P.I and Ajibola, A.A. (2013): The Effect of Gasoline Price on Economic Sectors in Nigeria. International Journal of Energy Economics and Policy 3(1).

[15] Obasi, N. K. (2003): Foreign participate in the Nigeria oil and gas industry. URL (last checked 26 December 2011). Management of Education in Nigeria, Jos. NAEAP Publication. Pp. 151-158.

[16] Obayi, O.A., Eme, O. and Emeh, I.E.J. (2012). The Domestic and International Implications of Fuel Subsidy Removal Crisis In Nigeria. Kuwait Chapter of Arabian Journal of Business and Management Review 1 (6)

[17] Okezie, A.I. (2012). Good Governance and basic infrastructure development: Its impact on growth and poverty reduction in
Nigeria. International Journal of Advancement in Economic Science. 4(1).

[18] Onyeizugbe, C.Z and Onwuka, E.M., (2012): Fuel Subsidy Removal as an Imperative for Enhancing Business Development in Nigeria. VSRD International Journal of Business \& Management Research. 2 (9).

[19] Plante, M. (2013): The Long-run Macroeconomic Impacts of Fuel Subsidies. Journal of Development Economics. 107, 129-143.

[20] PPPRA, (2012): Petroleum Product Pricing Regulatory Agency in Nigeria. http://www.pppra-nigeria.org.

[21] Siddig, K., Aguiar, A., Grethe, H., Minor, P., and Walmsley, T. (2014). Impacts of Removing Fuel Import Subsidies in Nigeria on Poverty. Energy Policy.

[22] Terfa W. A (2014). Enhancing Energy Access in Nigeria. National Institute for Legislative Studies (NILS) National Assembly, Abuja. 